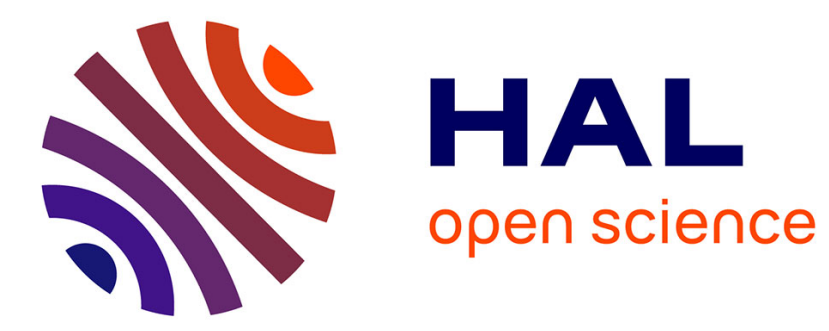

\title{
Area Postrema Syndrome as the Initial Presentation of Alexander Disease
}

Florence Renaldo, François Chalard, Stephanie Valence, Lydie Burglen, Diana Rodriguez

\section{- To cite this version:}

Florence Renaldo, François Chalard, Stephanie Valence, Lydie Burglen, Diana Rodriguez. Area Postrema Syndrome as the Initial Presentation of Alexander Disease. Neurology, 2021, 97 (11), pp.548-549. 10.1212/WNL.0000000000012462 . hal-03373412

\section{HAL Id: hal-03373412 https://hal.sorbonne-universite.fr/hal-03373412}

Submitted on 11 Oct 2021

HAL is a multi-disciplinary open access archive for the deposit and dissemination of scientific research documents, whether they are published or not. The documents may come from teaching and research institutions in France or abroad, or from public or private research centers.
L'archive ouverte pluridisciplinaire HAL, est destinée au dépôt et à la diffusion de documents scientifiques de niveau recherche, publiés ou non, émanant des établissements d'enseignement et de recherche français ou étrangers, des laboratoires publics ou privés. 


\section{Neurology}

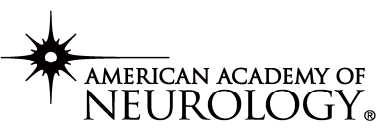

The most widely read and highly cited peer-reviewed neurology journal The Official Journal of the American Academy of Neurology

Neurology Publish Ahead of Print

DOI: 10.1212/WNL.0000000000012462

Area Postrema Syndrome as the Initial Presentation of Alexander Disease

\section{Author(s):}

Florence Renaldo, $\mathrm{MD}^{1}$; François Chalard, $\mathrm{MD}^{2}$; Stephanie Valence, MD, $\mathrm{PhD}^{1}$; Lydie Burglen, MD,

$\mathrm{PhD}^{3}$; Diana Rodriguez, $\mathrm{MD}, \mathrm{PhD}^{4}$

Neurology® Published Ahead of Print articles have been peer reviewed and accepted for publication. This manuscript will be published in its final form after copyediting, page composition, and review of proofs. Errors that could affect the content may be corrected during these processes. 
Corresponding Author:

Florence Renaldo

florence.renaldo@aphp.fr

Affiliation Information for All Authors: 1. Service de Neuropédiatrie \& Centre de Référence Neurogénétique, APHP.SU, Hôpital Trousseau, Paris, France; 2. Department of Pediatric Imaging, APHP.SU, Hôpital Trousseau, Paris, France; 3. Département de génétique médicale, APHP.SU, Hôpital Armand Trousseau; Developmental Brain Disorders Laboratory Imagine Institute, INSERM UMR 1163; Paris, France; 4. Service de Neuropédiatrie \& Centre de Référence Neurogénétique, APHP.SU, Hôpital Trousseau; Sorbonne Université, Inserm U1141- FHU I2-D2; Paris, France;

\section{Contributions:}

Florence Renaldo: Drafting/revision of the manuscript for content, including medical writing for content; Major role in the acquisition of data; Study concept or design; Analysis or interpretation of data François Chalard: Drafting/revision of the manuscript for content, including medical writing for content; Major role in the acquisition of data; Analysis or interpretation of data; Additional contributions: F. Chalard analyzed and interpreted the radiologic data.

Stephanie Valence: Drafting/revision of the manuscript for content, including medical writing for content; Analysis or interpretation of data

Lydie Burglen: Drafting/revision of the manuscript for content, including medical writing for content; Analysis or interpretation of data; Additional contributions: L. Burglen interpreted the genetic data.

Diana Rodriguez: Drafting/revision of the manuscript for content, including medical writing for content; Analysis or interpretation of data

Number of characters in title: 54

Abstract Word count:

Word count of main text: 100

References: 2

Figures: 1

Tables: 0

Neuroimage Legend Count: 49

Search Terms: [ 120 ] MRI, [ 227 ] All Pediatric

Acknowledgements: The authors thank the patient for granting permission to publish this information.

Study Funding: The authors report no targeted funding 
Disclosures: All the authors report no disclosures relevant to the manuscript: F Renaldo reports no disclosures relevant to the manuscript.F Chalard reports no disclosures relevant to the manuscript. S Valence reports no disclosures relevant to the manuscript.L Burglen reports no disclosures relevant to the manuscript. D Rodriguez reports no disclosures relevant to the manuscript.

A 16-year-old boy presented with six years evolution of anorexia, failure to thrive, nocturnal vomiting, and dysphagia. He was exhaustively explored. Neurologic examination was normal except hoarse voice. MRI revealed a hyperintensity of the area postrema (figure).

Faced with this chronic and isolated area postrema syndrome we looked for Alexander disease rather than neuromyelitis optica spectrum disorder. GFAP gene sequencing identified a reported, de novo, heterozygous variant c.1290C>A;p.Arg430Arg ${ }^{1}$.

Several patients with juvenile onset or type II Alexander disease have been reported with episodic vomiting, anorexia, and MRI lesions which can retrospectively be recognized as an impairment of the area postrema. ${ }^{2}$

Appendix 1: Authors

\begin{tabular}{|l|l|l|}
\hline Name & Location & Contribution \\
\hline $\begin{array}{l}\text { Florence } \\
\text { Menaldo, }\end{array}$ & $\begin{array}{l}\text { Service de Neuropédiatrie \& Centre de } \\
\text { Référence Neurogénétique, APHP.SU, } \\
\text { Hôpital Trousseau, Paris, France }\end{array}$ & $\begin{array}{l}\text { designed the study, collected and } \\
\text { analyzed the data, drafted the } \\
\text { manuscript }\end{array}$ \\
\hline $\begin{array}{l}\text { François } \\
\text { Chalard, } \\
\text { MD }\end{array}$ & $\begin{array}{l}\text { Department of Pediatric Imaging, } \\
\text { France }\end{array}$ & $\begin{array}{l}\text { analyzed and interpreted the } \\
\text { radiologic data }\end{array}$ \\
\hline $\begin{array}{l}\text { Stephanie } \\
\text { Valence, } \\
\text { MD, PhD }\end{array}$ & $\begin{array}{l}\text { Service de Neuropédiatrie \& Centre de } \\
\text { Référence Neurogénétique, APHP.SU, } \\
\text { Hôpital Trousseau, Paris, France }\end{array}$ & $\begin{array}{l}\text { analyzed the data, critically } \\
\text { reviewed and revised the manuscript }\end{array}$ \\
\hline $\begin{array}{l}\text { Lydie } \\
\text { Burglen, } \\
\text { MD, PhD }\end{array}$ & $\begin{array}{l}\text { Département de génétique médicale \& } \\
\text { Centre de Référence Neurogénétique, } \\
\text { APHP.SU, Hôpital Trousseau ; } \\
\text { Developmental Brain Disorders } \\
\text { Laboratory Imagine Institute, INSERM } \\
\text { UMR 1163; Paris, France }\end{array}$ & interpreted the genetic data. \\
& $\begin{array}{l}\text { Sorbonne Université, Service de } \\
\text { Neuropédiatrie \& Centre de Référence } \\
\text { Neurogénétique, APHP.SU, Hôpital } \\
\text { Trousseau; Inserm U1141- FHU I2- } \\
\text { D2 ; Paris, France }\end{array}$ & $\begin{array}{l}\text { analyzed the data, critically } \\
\text { reviewed and revised the manuscript }\end{array}$ \\
\hline $\begin{array}{l}\text { Diana } \\
\text { Rodriguez, } \\
\text { MD, PhD }\end{array}$ & \\
& & \\
& & \\
&
\end{tabular}




\section{References:}

1. Helman G, Takanohashi A, Hagemann TL, et al. Type II Alexander disease caused by splicing errors and aberrant overexpression of an uncharacterized GFAP isoform. Hum Mutat 2020; 41:1131-1137.

2. Niinikoski H, Haataja L, Brander A, et al. Alexander disease as a cause of nocturnal vomiting in a 7-year-old girl. Pediatr Radiol. 2009;39:872-875.

Legend to figure:

MRI shows lesion in the area postrema with T1-weighted hypointensity (A), contrast enhancement $(B, C)$ and FLAIR (D) and T2-weighted (E-G) hyperintensity. Apart from a vermian lesion with FLAIR (D) hyperintensity, MRI finds no significant abnormalities of the supratentorial white matter nor basal ganglia $(\mathrm{G}, \mathrm{H})$ nor spinal cord (not shown).
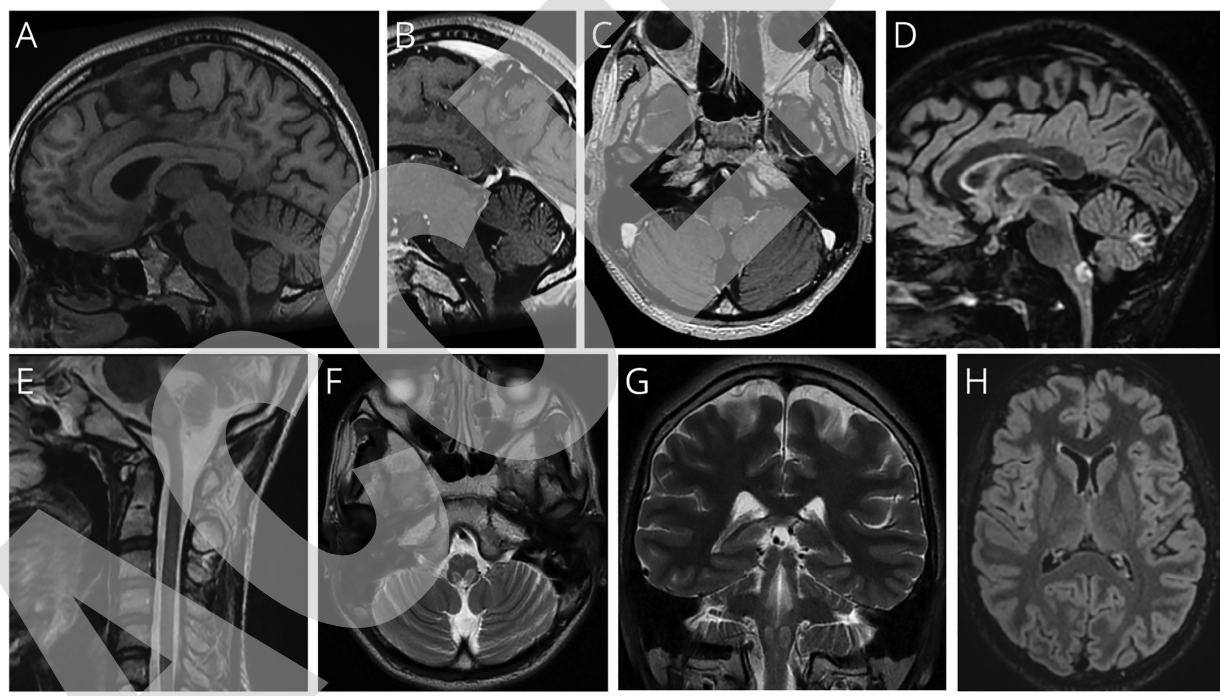


\section{Neurology}

\section{Area Postrema Syndrome as the Initial Presentation of Alexander Disease}

Florence Renaldo, François Chalard, Stephanie Valence, et al.

Neurology published online July 7, 2021

DOI 10.1212/WNL.0000000000012462

\section{This information is current as of July 7, 2021}

Updated Information \&

Services

Subspecialty Collections

Permissions \& Licensing

Reprints including high resolution figures, can be found at:

http://n.neurology.org/content/early/2021/07/07/WNL.0000000000012462. citation.full

This article, along with others on similar topics, appears in the following collection(s):

All Pediatric

http://n.neurology.org/cgi/collection/all_pediatric

MRI

http://n.neurology.org/cgi/collection/mri

Information about reproducing this article in parts (figures,tables) or in its entirety can be found online at:

http://www.neurology.org/about/about_the_journal\#permissions

Information about ordering reprints can be found online:

http://n.neurology.org/subscribers/advertise

Neurology ${ }^{\circledR}$ is the official journal of the American Academy of Neurology. Published continuously since 1951, it is now a weekly with 48 issues per year. Copyright (C) 2021 American Academy of Neurology. All rights reserved. Print ISSN: 0028-3878. Online ISSN: 1526-632X.

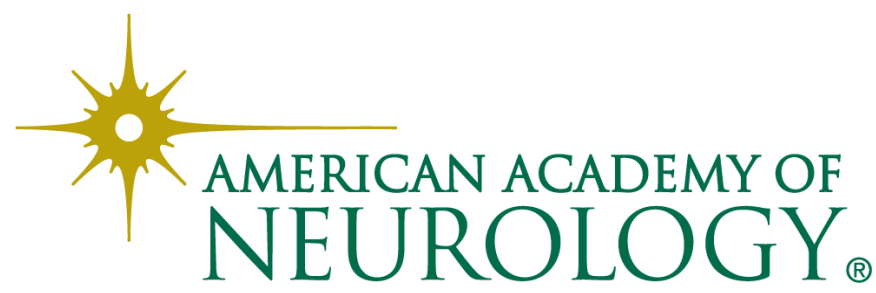

